\title{
MYCOGURT PEMBERDAYAAN IBU RUMAH TANGGA DALAM PENINGKATAN PENDAPATAN MASYARAKAT DI CILANGKAP, DEPOK
}

\author{
Dalia Sukmawati $^{*}$, Atin Supiyani ${ }^{2}$, Zakiah Nur Afifah $^{3}$, Umi Khumaiya ${ }^{4}$
}

1Program Studi Biologi, Fakultas Matematika dan Ilmu Pengetahuan Alam, Universitas Negeri Jakarta, Lantai 9 Lab. Mikrobiologi Kampus A, Rawamangun Muka, Jakarta Timur, Jakarta

\begin{abstract}
Abstrak
Yoghurt merupakan minuman susu fermentasi yang memiliki kandungan nilai gizi yang tinggi, kaya manfaat serta rasa yang lezat. Kandungan nilai gizi yang terdapat pada yoghurt meningkat akibat adanya proses fermentasi yang dilakukan oleh bakteri "starter" yoghurt. Bakteri mendegradasi komponen susu dan mensintesis berbagai zat tambahan lain seperti asam laktat dan vitamin. Pemanfaatan minuman fermentasi dalam meingkatkan kesehatan dan pendapatan keluarga akan dilakukan pada pengabdian ini. Mycogurt adalah salah satu produk minuman fermentasi yang dapat meningkatkan kesehatan. Kegiatan bertujuan memberikan penyuluhan mengenai manfaat, cara pembuatan yogurt dan analisis dibidang usaha guna peningkatan pendapatan masyarakat di Cilangkap Depok di lingkungan warga RT 03/11. Hasil kegiatan menunjukkan bahwa stater bakteri yang digunakan dapat mengentalkan susu setalah 24 jam inkubasi. Proses pembuatan yogur tberbahan dasar susu dapat menambah informasi dan pendapatan masyarakat. Sosialisasi dan sharing pengetahuan serta pengalaman mengenai teknik pembuatan yogurt dan bagaimana analisis finansialnya dilakukan kepada 25 peserta aktif dalam pelatihan. Hasil kegiatan mendapat mendapat respon yang cukup baik. Kegiatan ini diharapkan dapat dilakukan secara periodik, sehingga masyarakat mendapatkan manfaat bagi peningkatan pendapatannya.
\end{abstract}

Kata kunci: Mycogurt, Fermentasi, Bakteri

\begin{abstract}
Yogurt is a dairy-fermented beverage that has a high nutritional value, rich in benefits and delicious flavors. The nutritional value of yogurt is increased due to the fermentation process carried out by the yogurt "starter" bacteria. Bacteria degrade milk components and synthesize various other additives such as lactic acid and vitamins. The use of fermented drinks in improving health and family income will be carried out in this activity. "Mycogurt" is a fermented beverage product that can improve health. The activity aims to provide counseling about the benefits, how to make yogurt and business analysis in order to increase community income in Cilangkap, Depok, RT 03/11. This activity resulted that the bacterial starter used could thicken milk after 24 hours of incubation. The process of making milkbased yogurt can increase information and community income. The socialization and sharing of knowledge and experience regarding the technique of making yogurt and how the financial analysis was carried out on 25 active participants in the training. The results of the activity got a pretty good response. This activity is expected to be carried out periodically, so that the community get benefits from increased income.
\end{abstract}

Keywords: Mycogurt, Fermentation, Bacteria

Correspondence author: Dalia Sukmawati, dalia-Sukmawati@unj.ac.id, Jakarta, Indonesia

This work is licensed under a CC-BY-NC 


\section{PENDAHULUAN}

Salah satu bentuk pengabdian dan Tri Darma Perguruan Tinggi bagi para dosen adalah melakukan suatu kegiatan pengabdian masyarakat. Upaya pengabdian merupakan salah satu upaya realisasi undang-undang kependidikan. Disamping itu konversi statuta IKIP Jakarta menjadi Universitas Negeri Jakarta pada tahun 1999 melalui Keputusan Presiden No. 093/1999 tanggal 4 Agustus 1999.

Yoghurt merupakan minuman susu fermentasi yang memiliki kandungan nilai gizi yang tinggi, kaya manfaat serta rasa yang lezat. Kandungan nilai gizi yang terdapat pada yoghurt meningkat akibat adanya proses fermentasi yang dilakukan oleh bakteri "starter" yoghurt. Bakteri mendegradasi komponen susu dan mensintesis berbagai zat tambahan lain seperti asam laktat dan vitamin (Chotimah, 2009). Beberapa vitamin yang terkandung dalam yoghurt adalah vitamin B1 (tiamin), vitamin B2 (riboflavin), vitamin B3 (niasin), dan vitamin B6 (piridoksin) (Surajudin et al., 2005). Nilai gizi yang tinggi yang terdapat yoghurt membuat yoghurt memiliki banyak manfaat bila dikonsumsi. Beberapa manfaat tersebut ialah menjaga keseimbangan mikroflora dalam saluran pencernaan (Jannah et al., 2014) menurunkan kolesterol (Ishmayana et al., 2015) dan meningkatkan daya tahan tubuh (Chotimah, 2009).

Meski memiliki kandungan nilai gizi yang tinggi dan kaya manfaat, yogurt belum dijadikan sebagai pilihan utama dalam upaya pemenuhan gizi oleh seluruh kalangan masyarakat Indonesia. Hal ini disebabkan oleh adanya preferensi konsumen yang berbeda-beda terhadap rasa dan tekstur dari produk yoghurt. Hasil penelitan Jannah et al., (2014)yang menyebutkan bahwa konsumen yoghurt lebih memilih yogurt memiliki rasa manis dan tekstur lembut dibandingkan yogurt dengan rasa dan bau asam yang kuat. Rasa yoghurt lokal yang beredar di pasaran cenderung memiliki rasa yang asam dengan tekstur yang cair, sementara yoghurt impor memiliki tekstur yang sangat kental yang kurang disukai oleh konsumen di Indonesia. Tidak terpenuhinya preferensi produk yoghurt yang diinginkan oleh konsumen dapat dijadikan sebagai peluang dalam mengembangkan bisnis usaha yogurt.

Hasil produk akhir yogurt seperti tingkat keasaman, tekstur, kandungan zat gizi, warna, dan rasa dipengaruhi oleh komposisi bahan yang digunakan, persentase dan komposisi jenis kultur bakteri yang ditambahkan, serta suhu dan lama inkubasi yogurt. Pengunaan komposisi jenis bakteri yang digunakan sebagai "starter" akan menghasilkan produk akhir yogurt yang berbeda. Penelitian Sunarlim dan Usmiati (2006) menunjukan bahwa penggunan kombinasi jenis bakteri yang berbeda akan menghasilkan produk yoghurt yang berbeda dari tingkat keasaman dan tekstur produk yoghurt yang dihasilkan. Perbedan hasil yoghurt tersebut terjadi akibat adanya peran yang berbeda masing masing bakteri dalam proses fermentasi. Berdasarkan latar belakang di atas, dilakukan penelitian isolasi dan optimasi komposisi inokulat bakteri untuk menghasilkan produk yogurt "Mycogurt" yang sesuai dengan preferensi pasar di Indonesia.

Berdasarkan kondisi ini, perlu diupayakan kesadaran masyarakat akan pentingnya menjaga peningkatan kreativitas masyarakat berbasis hasil laboratorium. Melalui penyuluhan diharapkan masyarakat akan menyadari bahwa mereka dapat memanfaatkan hasil produk sekitar untuk meningkatkan kesejahteraan. Kegiatan akan dilakukan di daerah Cilangkap, Depok di lingkungan warga RT 03/11. 


\section{METODE PELAKSANAAN}

Kegiatan pengabdian kepada masyarakat ini dilakukan pada pada bulan Oktober 2019. Bahan-bahan yang digunakan adalah benih susu, gula, bakteri stater, panci, pemanas, botol kemasan, perasa, buah-buahan, kamera, penggaris, alat tulis, $\mathrm{pH}$ indikator, tabung reaksi, dan perlengkapan uji fermentasi. Langkah kerja dilakukan melalui fermentasi, pengujian fermentasi yogurt, uji organoleptic, pengemasan, dan packing, serta penyuluhan analisis finansial, dan kegiatan sosialisasi. Kegiatan terdiri dari:

1. Pendahuluan

Pada tahapan ini akan dilaksanakan pengumpulan data mengenai kondisi lingkungan terutama kebiasaan masyarakat dalam menjaga kesehatan lingkungan di sekitar kelurahan Cilangkap, Kelurahan Tapos, Kota Depok, Jawa Barat 16458.

2. Perencanaan \& Persiapan

Pada tahapan ini akan dilaksanakan penyusunan rencana kerja yang meliputi antara lain: menyiapkan alat dan bahan di laboratorium mikrobiologi terutama yang akan dipergunakan untuk pengujian di lapangan, menyiapkan modul-modul penyuluhan, dan mengatur waktu kegiatan penyuluhan dan pelaksanaan pengujian.

3. Pelaksanaan

Pelaksanaan penyuluhan dilakukan melalui penyampaian materi modul-modul penyuluhan dan demonstrasi teknik pembuatan yogurt dan aplikasi berbasi nata de coco yang kaya akan fiber, serta diskusi (tanya jawab). Penyuluhan dilakukan dalam satu kali pertemuan waktu 90-120 menit. Metode yang akan dilaksanakan dalam kegiatan ini antara lain adalah:

a. Metode ceramah atau penyuluhan yaitu memberikan penyuluhan kepada para peserta tentang berbagai manfaat minuman fermentasi yogurt, cara pembuatan dan bagaimana teknik packing.

b. Metode demonstrasi (pelatihan) yaitu melakukan demonstrasi pelatihan pembuatan minuman fermentasi berbasis aplikasi hasil mikroorganisme, bagaimana proses packing dan pemasaran dan bagaimana hitungan ekonominya.

c. Diskusi dan tanya jawab tentang permasalahan aktual di masyarakat serta pemecahannya.

4. Evaluasi

Pada tahapan ini dilakukan evaluasi hasil dari kegiatan yang telah dilakukan.

\section{HASIL DAN PEMBAHASAN}

Kegiatan pengabdian masyarakat merupakan kegiatan Tridarma Perguruan Tinggi yang harus terus dilakasnakan selaku tenaga pendidik. Implementasi dari kegiatan di laboratorium kemudian masyarakat dapat merasakan manfaat dan hasil penelitian merupakan wujud utama dalam peningkatan kesejakteraan masyarakat. Lokasi pengabdian dilakukan di Cilangkap, Tapos, Kota Depok, Jawa Barat 16458 (Gambar 1). 


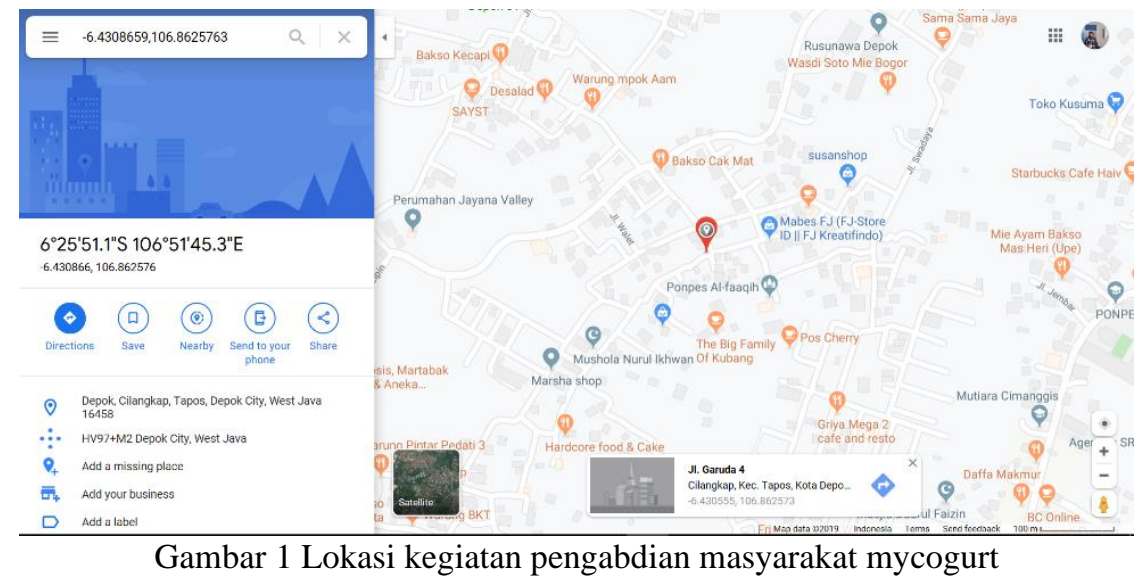

Kegiatan di lakukan di kelurahan Cilangkap, Tapos, Kota Depok, Jawa Barat 16458. Wilayah padat penduduk, dengan keadaan perekonomian yang bervariasi, taraf pencarian mata penghasilan yang sangat beragam, ada yang sebagai PNS, pegawai swasta maupun ada juga yang mengandalkan hasil kebun di wilayah setempat. Penduduk di sana sangat ramah dan tertata dalam hal menjaga kebersihan lingkungan. Lingkungan kelurahan Cilangkap, Tapos, Kota Depok, Jawa Barat 16458 memiliki tata kelola yang baik dalam pembinaan warganya. Kegiatan pengabdian dilakukan di kediaman kader masyarakat pembina ibu-ibu kelompok wanita PKK yaitu Ibu Neneng. Kegiatan berlangsung pada tanggal 12 Oktober 2019. Kegiatan tidak hanya terdiri dari pemberian materi berupa "Mycogurt Pemberdayaan Ibu Rumah Tangga Dalam Peningkatan Pendapatan Masyarakat" dan cara praktek pembuatannya, akan tetapi juga dilakukan penyuluhan diabetis dan cara pencegahannya oleh tim dosen Biologi yaitu drh. Atin Supiyani, M.Si.

\section{Persiapan Pembuatan Stater Yogurt sebagai minuman Sehat Probiotik}

Probiotik telah digunakan oleh orang-orang di dunia sejak konsumsi makanan fermentasi mulai dilakukan (FAO/WHO, 2006). Probiotik merupakan mikroorganisme hidup yang apabila diberikan dalam jumlah optimal dapat memberikan manfaat kesehatan bagi inangnya. Konsumsi probiotik memiliki berbagai manfaat, sebagai aktivitas hipokolesterolemia dengan menurunkan kolesterol plasma (Liong dan Shah, 2005), mencegah dan mengobati diare (FAO/WHO, 2006), dan mengubah sistem kekebalan tubuh menjadi lebih baik. Asupan mikroorganisme probiotik secara teratur dan dalam jumlah yang cukup ini diharapkan dapat memgoptimalkan fungsi usus, stimulasi sistem kekebalan tubuh dan penghambatan patogen dalam tubuh (Amorim, Piccoli, \& Duarte, 2018).

Mekanisme probiotik yang memberikan efek menguntungkan pada inang harus mampu tumbuh dan berkembang pada kondisi penurunan $\mathrm{pH}$ pada usus, mampu melakukan proses adhesi sebagai sumber nutrisi, sekresi zat antibakteri, inaktivasi toksin, dan stimulasi kekebalan tubuh (Salminen et al., 2010).

Karakteristik utama mikroorganisme probiotik yaitu mempunyai mekanisme toleransi yang tinggi terhadap kondisi asam dan empedu pencernaan serta mampu menghambat pembentukan dan replikasi patogen dalam saluran pencernaan (Shukla, Sharma, \& Goyal, 2010). Salah satu kriteria yang harus dimiliki oleh mikroorganisme probiotik adalah mampu untuk tumbuh dan bertahan hidup melewati kondisi stres tubuh manusia. Probiotik harus mampu resisten terhadap enzim yang ada dalam rongga mulut 
seperti amilase dan lisozim (Fuller, 1992; Gilliland, 1979; Kõll-Klais et al., 2005). Setelah mampu bertahan dalam rongga mulut, probiotik akan menghadapi senyawa antibakteri yang ada dalam perut dan usus. Ketahanan terhadap kondisi stres menjadi salah satu syarat untuk mendapatkan agen probiotik seperti tahan pada cekaman asam lambung, $\mathrm{pH}$ rendah, cekaman bile, suhu tubuh, dan kemampuan mikroba dalam menghasilkan enzim. Salah satu minumam fermentasi yang mengandung mikrooganisme probiotik adalah yogurt. Kegiatan pendahuluan di laboratorium adalah melakukan isolasi dan mendapatkan kultur murni dari yogurt yang dimiliki oleh Universitas Negeri Jakarta Culture Collection (UNJCC). Kegiatan terdiri dari;

1. Isolasi Bakteri

Isolasi bakteri dilakukan dengan menggunakan media NA (Nutrien Agar) dan media SMA (Skim Milk agar). Hasil isolasi bakteri yogurt dari produk yogurt "Mycogurt" menghasilkan 3 isolat murni bakteri yogurt (Tabel 1). Ketiga isolat murni bakteri tersebut akan digunakan untuk tahapan selanjutnya.

Tabel 1. Karakter makroskopik isolat bakteri hasil isolasi asal produk yogurt "Mycogurt".

\begin{tabular}{ccclccc} 
& \multirow{2}{*}{ Kode } & \multicolumn{5}{c}{ Karakter makroskopik } \\
\cline { 3 - 6 } & Isolat & Warna koloni & $\begin{array}{l}\text { Permukaan } \\
\text { koloni }\end{array}$ & Tepi & Optik & Elevasi \\
\hline 1. & 1 & Putih & $\begin{array}{l}\text { Halus, } \\
\text { mengkilap }\end{array}$ & $\begin{array}{l}\text { Smooth, } \\
\text { entire }\end{array}$ & Translucent & Raised \\
\hline 2. & 2 & Putih & $\begin{array}{l}\text { Halus, } \\
\text { mengkilap }\end{array}$ & $\begin{array}{l}\text { Smooth, } \\
\text { entire }\end{array}$ & Translucent & Raised \\
\hline 3. & 3 & $\begin{array}{l}\text { Putih } \\
\text { kekuningan }\end{array}$ & $\begin{array}{l}\text { Halus, } \\
\text { mengkilap }\end{array}$ & $\begin{array}{l}\text { Smooth, } \\
\text { entire }\end{array}$ & Translucent & Raised \\
\hline
\end{tabular}

2. Uji Koagulasi Protein Susu

Koagulasi adalah keadaan di mana protein tidak lagi terdispersi sebagai suatu koloid karena unit ikatan yang terbentuk cukup banyak (Makfoeld, 2008). Uji Koagulasi protein susu dilakukan untuk menguji efektifitas kemampuan bakteri dalam menggunakan protein susu sebagai sumber karbonnya. Uji ini dilakukan dalam beberapa tahap yaitu uji koagulasi I, uji koagulasi II, dan uji konfirmasi koagulasi. Uji koagulasi I dilakukan untuk menguji kemampuan masing-masing isolat bakteri dalam menggumpalkan protein susu, uji koagulasi II dilakukan untuk menguji kemampuan kombinasi bakteri dalam menggumpalkan susu dan uji konfirmasi dilakukan untuk memeriksa ulang dan melihat konsistensi dari hasil uji koagulasi I dan II.

Hasil Uji koagulasi 1 menunjukan bahwa tidak semua isolat bakteri hasil isolasi mampu menggumpalkan protein susu yang terdapat pada tabung uji (Gambar 2). Hal ini terlihat dari hasil uji koagulasi I yang menunjukan hanya isolat 1 dan 2 yang mampu menggunakan protein susu sebagai sumber substratnya (Tabel 2).

Tabel 2. Hasil uji koagulasi I dengan menggunakan media susu UHT, waktu inkubasi $24-48$ jam dan suhu $35-37^{\circ} \mathrm{C}$.

\begin{tabular}{ccccl}
\hline No. & Isolat & $\mathrm{pH}$ & Koagulasi & \multicolumn{1}{c}{ Keterangan } \\
\hline 1. & 1 & 6 & + & $\begin{array}{l}\text { Warna susu berubah, bagian atas susu menjadi } \\
\text { jernih, dan terjadi penggumpalan susu pada } \\
\text { bagian bawah tabung }\end{array}$ \\
\hline
\end{tabular}




\begin{tabular}{llllll}
\hline 2. & 2 & 6 & + & \multicolumn{2}{l}{$\begin{array}{l}\text { Warna susu berubah, bagian atas susu menjadi } \\
\text { jernih, dan terjadi penggumpalan susu pada } \\
\text { bagian bawah tabung }\end{array}$} \\
\hline 3. & 3 & 6 & - & $\begin{array}{l}\text { Tidak terjadi perubahan warna dan } \\
\text { penggumpalan susu }\end{array}$ \\
\hline
\end{tabular}

Ketidakmampuan isolat 3 dalam menggumpalkan protein susu dapat dikarenakan ketidakesesuaian lingkungan hidup, seperti $\mathrm{pH}$ yang kurang asam, atau tidak terdapatnya zat prekusor lain untuk pertumbuhan dapat menyebabkan beberapa jenis BAL (Bakteri asam laktat) tidak dapat tumbuh dan berkembang (Naga et al., 2010). Chotimah (2009) memaparkan bahwa dalam proses fermentasi terdapat hubungan simbiosis obligat antar jenis bakteri yogurt yang digunakan dimana hasil metabolisme yang dihasilkan oleh suatu jenis bekteri akan digunakan sebagai prekursor bagi bakteri lainya.

Hasil uji koagulasi II dilakukan untuk mendapatkan kombinasi gabungan bakteri terbaik dalam mengumpalkan protein susu. Hasil uji koagulasi II menunjukan bahwa gabungan kombinasi bakteri 2 dan 3 merupakan gabungan kombinasi bakteri dengan kemampuan menggumpalkan susu terbaik (Gambar 2). Hal ini dapat terlihat dari menggumpalnya seluruh media susu UHT pada bagian bawah tabung uji dan terbentuknya cairan bening pada bagian atas tabung uji.

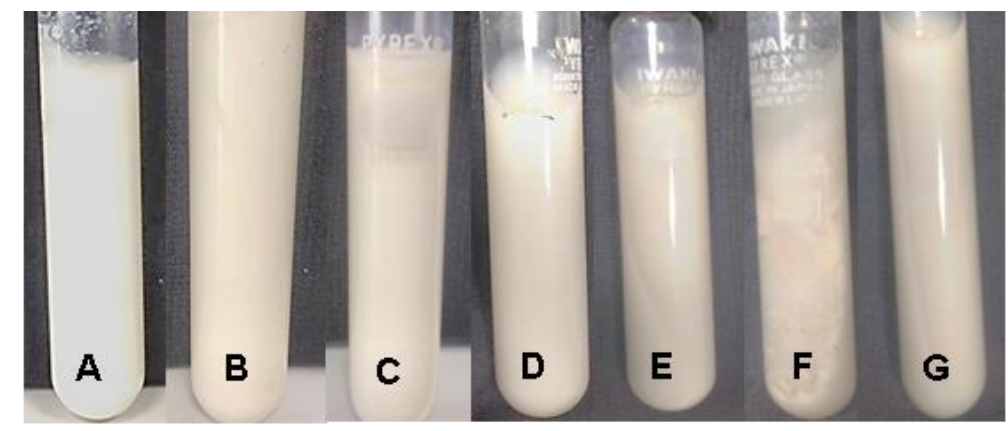

Gambar 2 Hasil uji koagulasi II dengan menggunakan media susu UHT, waktu inkubasi 24-48 jam dan suhu $35-37^{\circ} \mathrm{C}$. Isolat bakteri 1 (A), isolat bakteri $2(\mathrm{~B})$, isolat bakteri $3(\mathrm{C})$, isolat bakteri

1 dan 2 (D), isolat bakteri 1 dan 3 (E), isolat bakteri 2 dan $3(\mathrm{~F})$ dan isolat bakteri 1,2, dan 3 .

Hasil uji koagulasi II juga menunjukan bahwa kombinasi isolat bakteri 2 dan 3 menghasilkan nilai $\mathrm{pH}$ yang paling rendah dibandingkan dengan kombinasi isolat bakteri laiinya yang berkisar antara 6,5 - 6 (Tabel 3). Perbedaan nilai pH pada yogurt dapat disebabkan oleh adanya perbedaan jumlah produksi asam laktat yang dihasilkan. Produksi asam laktat dapat dipengaruhi oleh beberapa faktor diantaranya adalah jenis susu yang digunakan dan jenis strain bakteri yang digunakan. Penelitian Fatmawati, et al., (2013) menunjukan bahwa yogurt yang dihasilkan menggunakan bahan baku susu yang berbeda akan menghasilkan $\mathrm{pH}$ dan kandungan asam laktat yang berbeda pula. Semakin tinggi kadar laktosa yang terdapat pada susu maka semakin banyak laktosa yang dapat dipergunakan oleh bakteri. Hal ini membuat semakin rendah nilai $\mathrm{pH}$ dan semakin tinggi asam laktat yang dihasilkan pada produk yogurt (Hanzen et al., 2016). 
Tabel 3. Hasil uji koagulasi susu II dengan menggunakan media susu UHT, waktu inkubasi $24-48$ jam dan suhu $35-37^{\circ} \mathrm{C}$.

\begin{tabular}{|c|c|c|c|c|}
\hline No. & Isolat & pH & Koagulasi & Keterangan \\
\hline 1. & D1 & 6,5 & + & $\begin{array}{l}\text { Warna susu berubah, bagian bawah } \\
\text { susu mengental, terdapat cairan } \\
\text { berwarna transparan pada bagian } \\
\text { atas tabung }(++)\end{array}$ \\
\hline 2. & $\mathrm{D} 2$ & 6 & + & $\begin{array}{l}\text { Warna susu berubah, bagian bawah } \\
\text { susu mengental, terdapat sediki } \\
\text { cairan berwarna transparan pada } \\
\text { bagian atas tabung }(+)\end{array}$ \\
\hline 3. & D3 & 6,5 & - & Tidak terjadi penggumpalan susu \\
\hline 4. & D1 dan D2 & 6,5 & + & $\begin{array}{l}\text { Warna susu berubah, bagian bawah } \\
\text { susu mengental, terdapat sedikit } \\
\text { cairan berwarna transparan pada } \\
\text { bagian atas tabung }(+)\end{array}$ \\
\hline 5. & D1 dan D3 & 6 & + & $\begin{array}{l}\text { Warna susu berubah, bagian bawah } \\
\text { susu mengental, terdapat cairan } \\
\text { berwarna transparan pada bagian } \\
\text { atas tabung }(++)\end{array}$ \\
\hline 6. & D2 dan D3 & 5 & ++ & $\begin{array}{l}\text { Warna susu berubah, bagian bawah } \\
\text { susu mengental, terdapat cairan } \\
\text { berwarna transparan pada bagian } \\
\text { atas tabung }(++++)\end{array}$ \\
\hline 7. & D1, D2, dan D3 & 6,5 & + & $\begin{array}{l}\text { Warna susu berubah, bagian bawah } \\
\text { susu mengental, terdapat cairan } \\
\text { berwarna transparan pada bagian } \\
\text { atas tabung }(+++)\end{array}$ \\
\hline
\end{tabular}

Beberapa penelitian yogurt yang menggunakan susu UHT sebagai bahan bakunya memperlihatkan hasil akhir derajat keasaman yang mencapai 4,5 (Fatmawati, et al., 2013) hingga 4,19 (Zakaria et al., 2013). Berdasarkan hasil tersebut terlihat bahwa hasil uji koagulasi II kombinasi isolat bakteri 2 dan 3 memiliki derajat keasaman yg lebih tinggi dibandingkan beberapa penelitian laiinnya yang menggunakan bahan baku yg sama yaitu susu UHT. Derajat keasaman susu menurun seiring dengan konversi laktosa menjadi asam laktat melalui proses fermentasi oleh bakteri (Damian, 2014). Tingginya nilai $\mathrm{pH}$ pada hasil uji koagulasi II kombinasi isolat 2 dan 3 dapat sebabkan oleh jenis strain bakteri 2 dan 3 mampu menggumpalkan protein susu hanya dengan memproduksi sedikit asam laktat.

Diperolehnya biakan murni bakteri penghasil asam laktat dalam hal ini adalah bakteri yang digunakan sebagai stater digunakannya sebagai biang untuk proses fermentasi pembuatan yogurt.

\section{Kegiatan Pelaksanaan Pengabdian Masyarakat di Depok}

Kegiatan Pengabdian kepada Masyarakat tahun 2019 diawali dengan pendaftaran peserta pada pukul 08.00-09.00 di kediaman kader masyarakat pembina ibu-ibu kelompok wanita PKK, Ibu Neneng. Peserta kegiatan terdiri dari anggota PKK, tokoh masyarakat setempat dan anggota masyarakat lain dengan total peserta berjumlah 25 orang. Acara diawali dengan pembukaan dan pembacaan runutan kegiatan oleh mahasiswa Biologi angkatan 2016 (Gambar 3). 


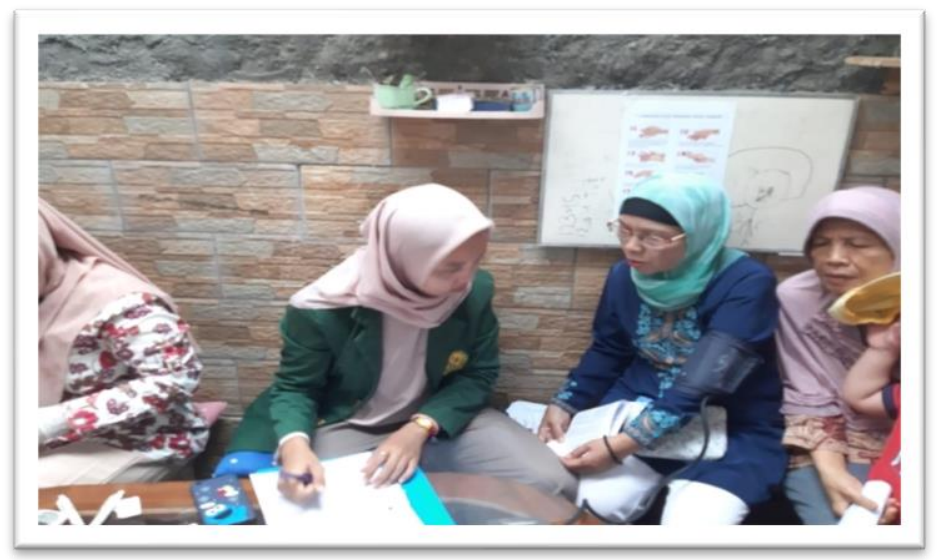

Gambar 3 Mahasiswa prodi Biologi angkatan 2016 membantu proses kegiatan PKM

Pembukaan kegiatan dimulai dengan sambutan ibu ketua RT setempat yaitu Ibu Atik yang memberikan ucapan terima kasih akan keinginan dan antusias warga dalam kegiatan pengabdian masyarakat. Ketua RT sekaligus ibu kader juga mengucapkan rasa terima kasih atas kesediaan dosen Prodi Biologi UNJ dalam menyempatkan waktunya dan mengajarkan ilmunya untuk memberikan pencerahan kepada masyrakat setempat. Kegiatan PKM ini terdiri dari beberapa topik kegiatan yaitu (1) Penjelasan mengenai mycogurt sebagai salah satu upaya dalam peningkatan pendapatan masyarakat; yang disampaikan oleh Dr. Dalia Sukmawati, M.Si, (2) penjelasan mengenai bahaya penyakit Diabetis dan jenis serta bagaimana proses dan upaya pencegahannya yang disampaikan oleh drh. Atin Supiyani, M.Si (Gambar 4).

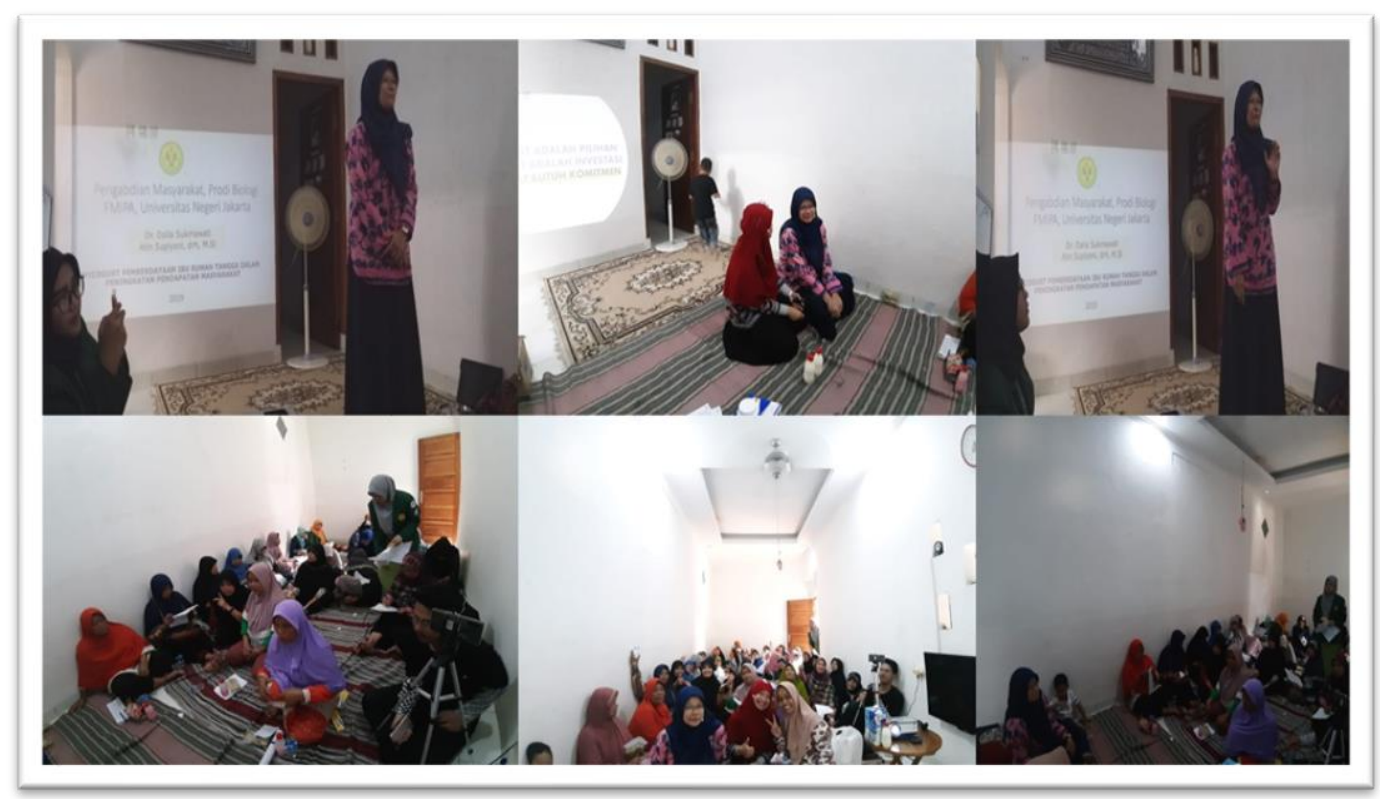

Gambar 4 Kegiatan Pengabdian Masyarakat

Pelaksanaan kegiatan berjalan lancar dan mendapat tanggapan yang sangat positif dari para peserta, dilihat dari banyaknya pertanyaan yang muncul serta antusiasme peserta 
selama kegiatan. Kegiatan di awali dengan pemberian soal pre-test yang bertujuan untuk melihat pemahaman masyarakat mengenai pengertian probiotik dan apa manfaatnya bagi kesehatan (Gambar 5).

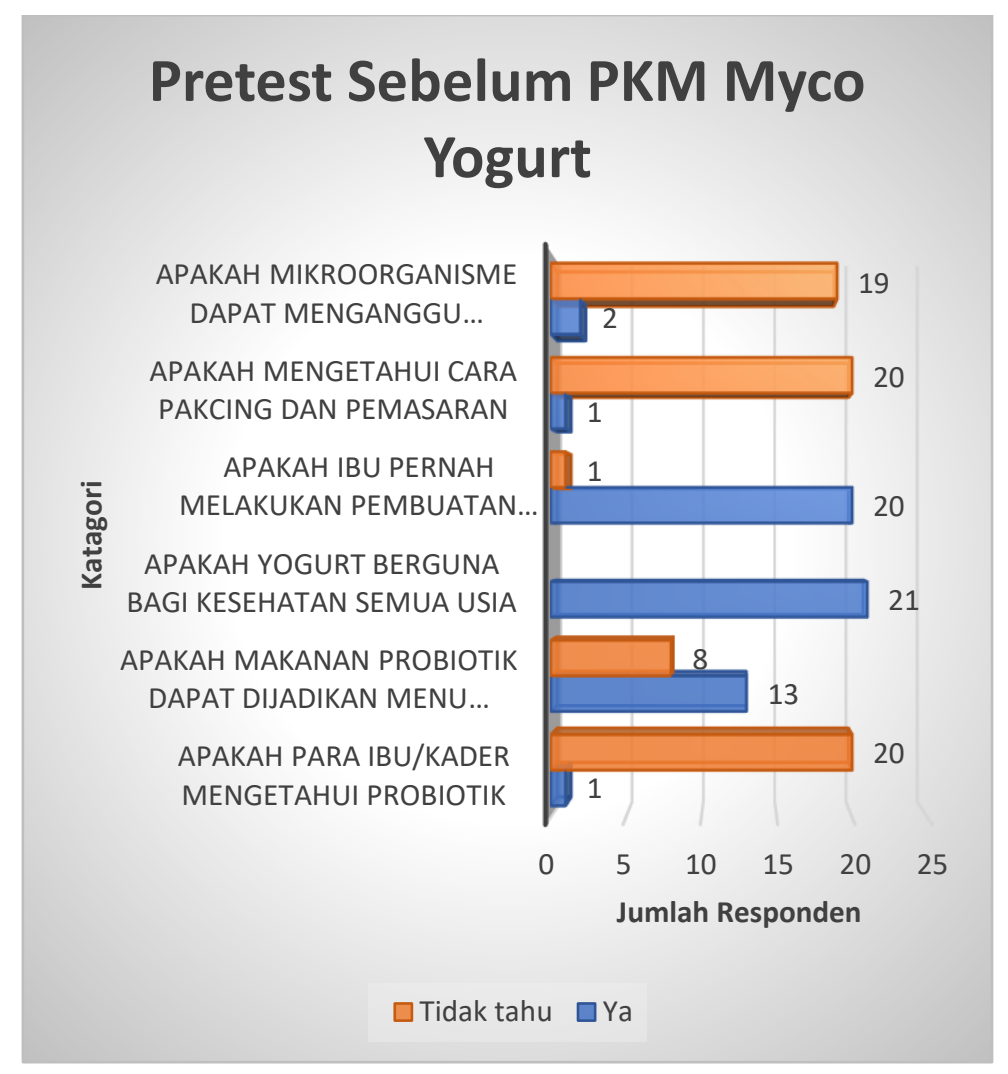

Gambar 5 Hasil responden para peserta pengabdian masyarakat 10 Oktober 2019

Uji pre-test dilakukan kepada para ibu dengan rentang usia 45-68 tahun yang aktif dalam kegiatan ini. Para ibu berprofesi sebagai ibu rumah tangga, kader PKK, dan pegawai. Dari 21 peserta rerata ibu menjawab tidak mengetahui mengenai pengertian probiotik dan manfaatnya bagi kesehatan dan hampir $90 \%$. Ibu-ibu para peserta kegiatan belum mengetahui manfaat probiotik dan bagaimana manfaatnya bagi kesehatan serta bagaimana cara mengolah dan membuatnya sehingga dapat meningkatkan penghasilan dan pendapatan masyarakat, terutama membantu para suami dalam meningkatkan pendapatan keluarga.

Kegiatan pengabdian dilakukan dengan penjelasan mengenai probiotik. Probiotik adalah mikroorganisme hidup yang dapat memperbaiki sistem pencernaan dan membantu penyerapan nutrisi dalam usus, sehingga kesehatan menjadi lebih terjaga. Pada kulit dan sistem pencernaan terdapat 2000 jenis spesies mikroorganisme yang berbeda yang dapat memberikan pengaruh. Penjelasan mengenai manfaat probiotik berupa: probiotik dapat menanggulangi diare (Czerucka, Piche, \& Rampal, 2007), menstimulasi kekebalan imun tubuh (Collado et al.,, 2009), mencegah terjadinya kanker kolon dan usus (Collado et al., 2009), meringankan sindrom iritasi usus (irritable bowel syndrome), meredakan gejala penyakit radang usus (inflammatory bowel disease), mencegah alergi dan pilek, menjaga kesehatan saluran kemih dan vagina, membantu meringankan gangguan kulit, menjaga kesehatan mulut serta menurunkan risiko infeksi pernapasan (Gambar 6). Selain 
dijelaskan mengenai peran dan manfaat probiotik bagi kesehatan, juga dijelaskan bagaimana proses pembuatandan pengolahan yogurt serta proses pengemasannya.

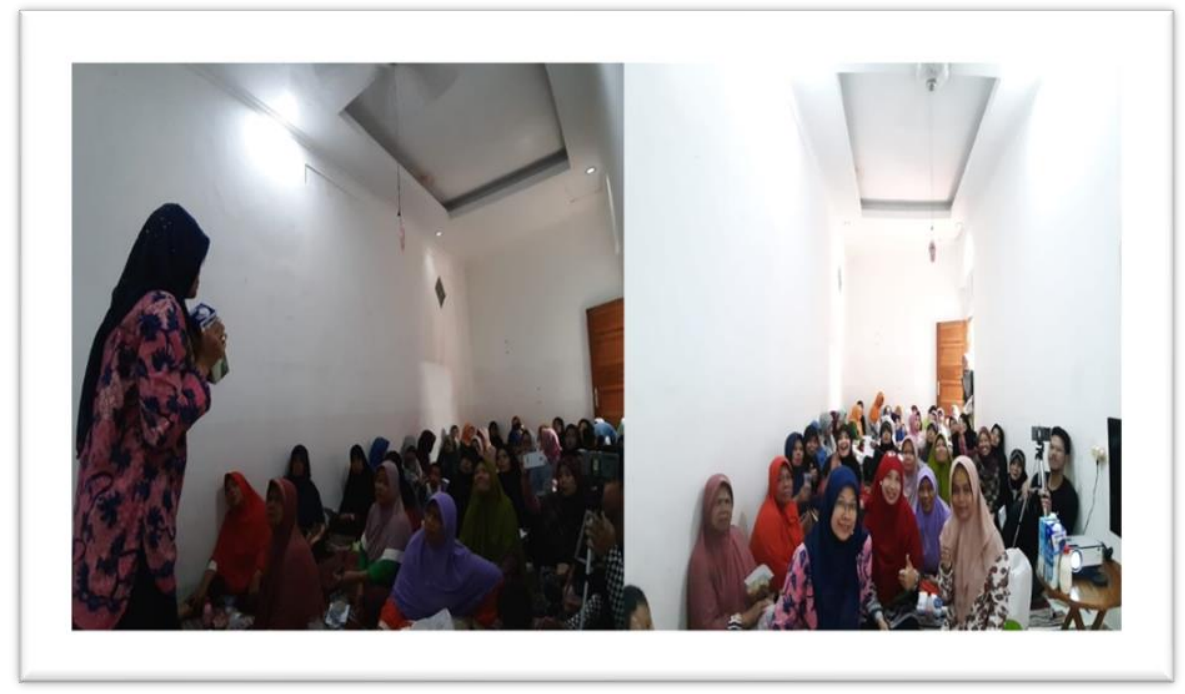

Gambar 6 Penjelasan mengenai probiotik dan proses pembuatan mycoyogurt

Penjelasan mengenai bagaimana proses pembuatan dan bagaimana cara pengolahan dan bahan-bahan apa saja yang harus disiapkan (Gambar 7). Bahan yang dipersiapkan untuk pmbuatan mycoyogurt berupa susu, stater bakteri asam laktat. Susu kemudian dilakukan sterilisasi dengan menggunakan panci almunium, dipanasakan sampai mendidih, kemudian didinginkan sampai suhu sekitar $40^{\circ} \mathrm{C}$. ketika susu sudah pada suhu hangat kuku, kemudian stater yogurt mulai dituangkan secara aseptis. Susu yang sudah diinokulaiskan dengan bakteri penghasil asam laktat kemudian diinkubasi atau didiamkan sampai sekitar 24 jam .

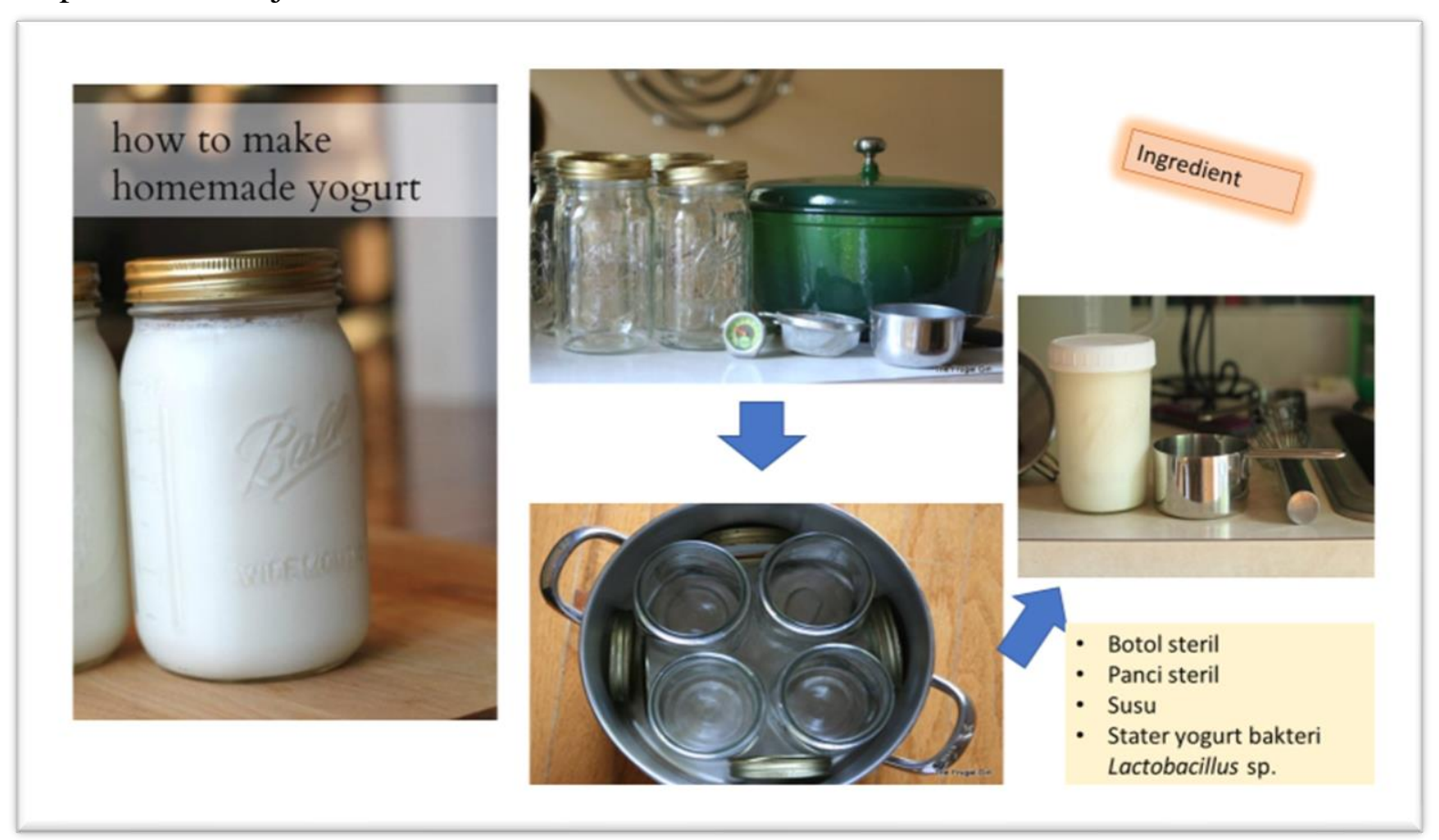

Gambar 7 Bahan dan alat yang diperlukan dalam proses pembuatan mycoyogut 
Setelah inkubasi selama 24 jam, yogurt telah berhasil dibuat kemudian siap untuk dilakukan pengolahan. Proses pengolahan dapat menggunakan cairan gula sebagai pemanis dengan penambahan essens atau sari buah asli. Jika semua telah dilakukan maka proses pengemasan telah selesai dan dapat dikonsumsi atau dipasarkan. Konsumsi yogurt dapat untuk semua usia dan kalangan. Konsumsi yogurt setiap hari akan meningkatkan kesehatan dan meningkatkan pendapatan masyarakat. Kegiatan kemudian ditutup dengan pemberian post-test dan hasil post-test menunjukkan hasil yang positif. Ibu-ibu kader mulai memamahi pentingnya mengkonsumsi probiotik, manfaatnya bagi kesehatan dan bagaimana cara pembuatannya. Hasil angket menunjukan rerata ibu-ibu sangat menyukai rasa dan tingkat kekentalan yogurt yang telah dibuat (Gambar 8).

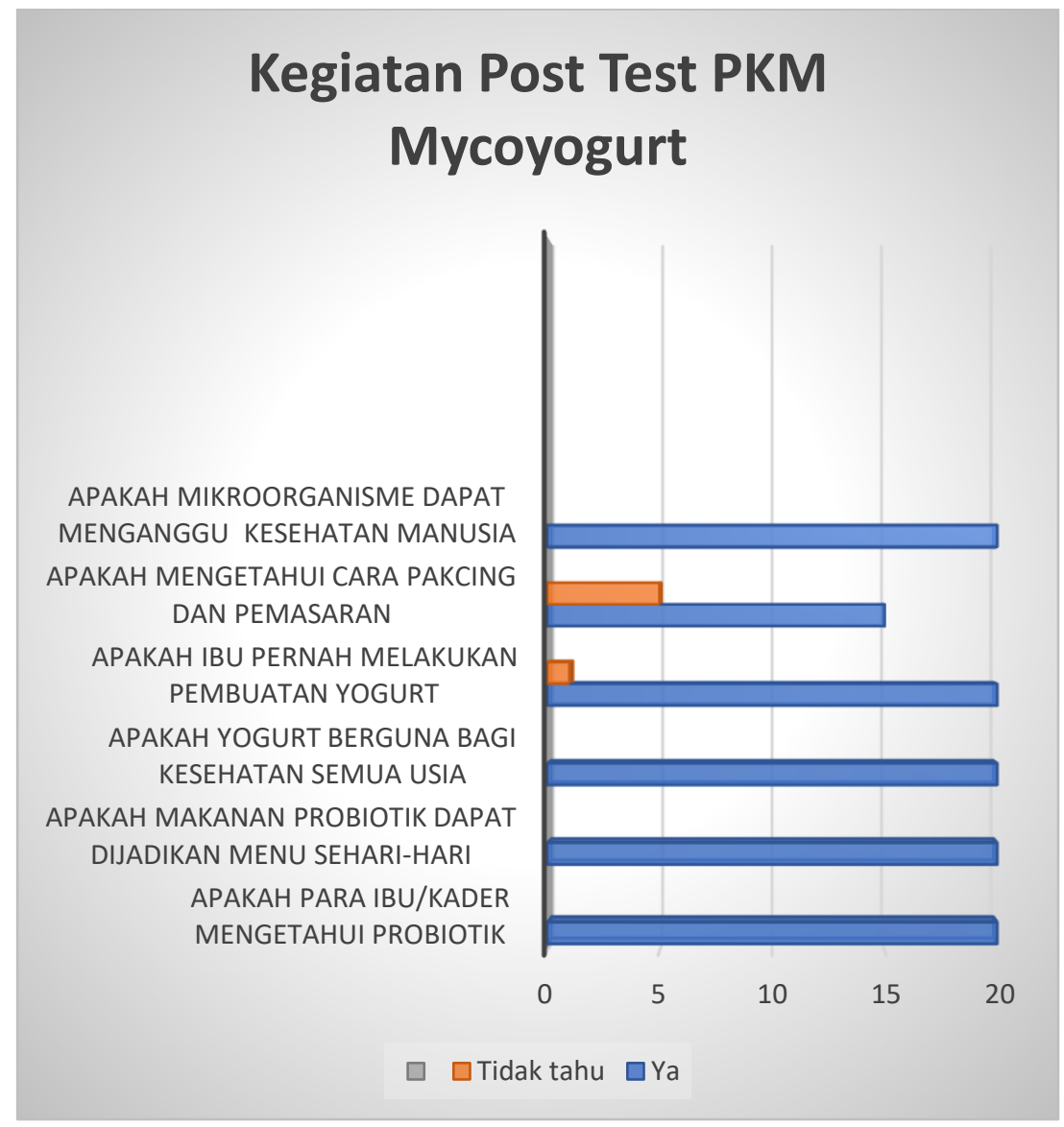

Gambar 8 Hasil post test kegiatan masyarat pembuatan mycogurt

Dari hasil post-test terlihat bahwa pengetahuan masyrakat menjadi bertambah, dan pengetahuan mengenai manfaat probiotik dan bagaimana cara pembuatan, pengolahan agar berdaya guna bagi masyarakat terutama dalam peningkatan pendapatan membuat acara kegiatan ini menjadi sangat menarik dan diikuti dengan sangat antusias. Hasil saran dan pesan dikatakan bahwa kegiatan pengabdian lebih ditingkatkan dengan menambah berbagai informasi dan pengetahuan akan produk inovasi dari prodi Biologi. Masyarakat sangat mengharapkan kegiatan ini menjadi kegiatan rutin yang dapat dilakukan dan ditingkatkan (Gambar 9). 

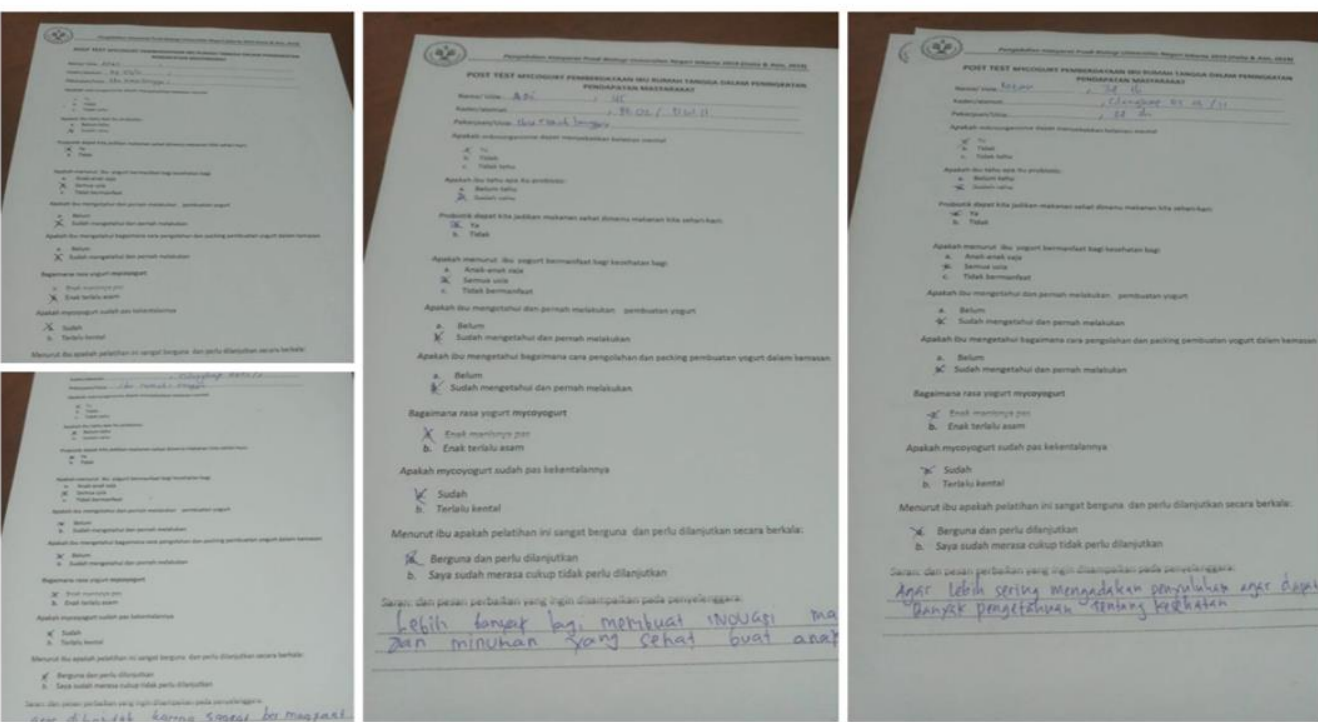

Gambar 9 Pretest dan post test para peserta kegiatan PKM mycoyogurt

Kegiatan dilanjutkan dengan penutupan dan ramah tamah sesama warga dan kader PKK Cilangkap RT.03/RW.11

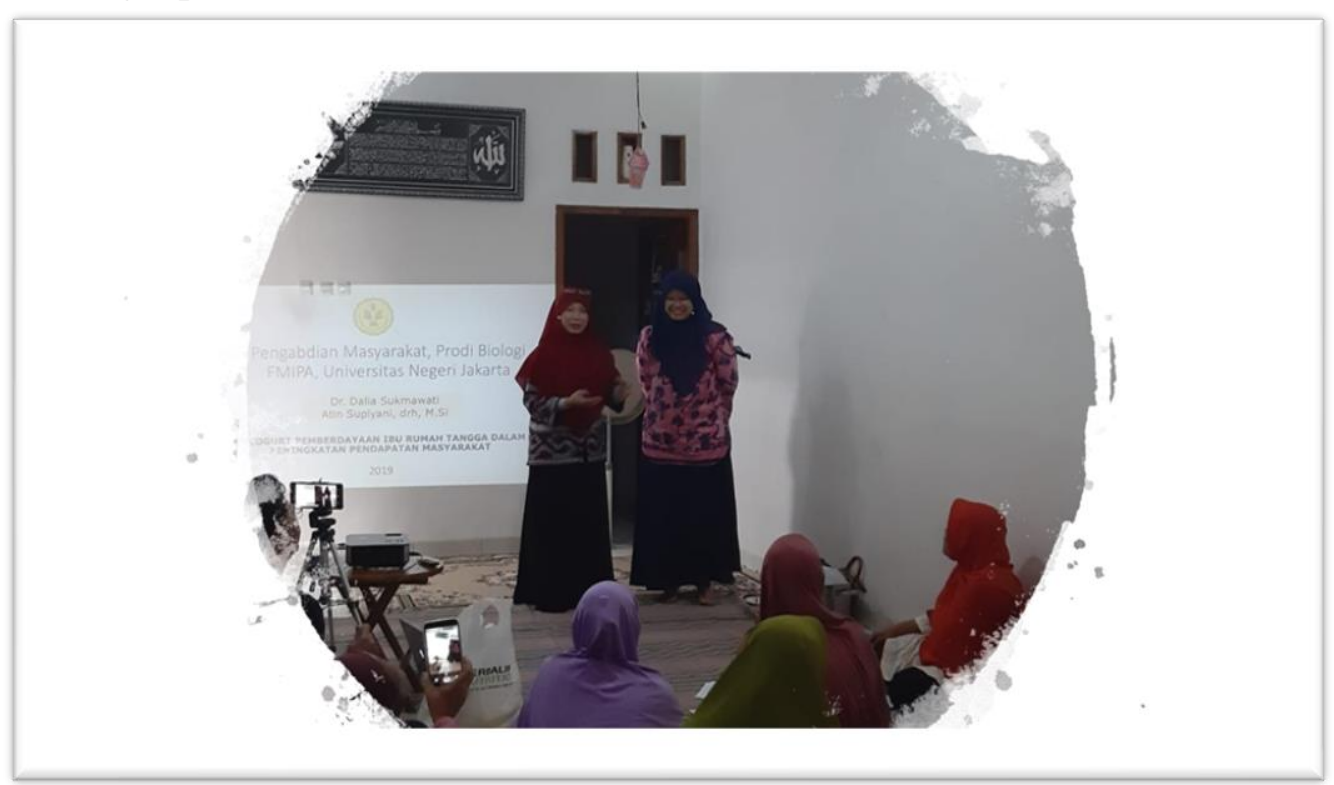

Gambar 10 Tim PKM mycogurt di Cilangkap, Tapos, Kota Depok, Jawa Barat 16458.

\section{SIMPULAN}

Pembuatan minuman fermentasi mycogurt merupakan hal yang bermanfaat bagi masyarakat sekitar Bekasi terutama masyarakat sekitar Rumah Kader Depok, Cilangkap, Tapos, Depok City, West Java 16458. Kegiatan yang dihadiri oleh remaja putri, ibu-ibu 
kader, ibu-ibu PKK menjadi sebuah proses pencerahan masyarakat sekitar dalam upaya peningkatan kemampuan pendapatan masyarakat terutama aplikasi probiotik dalam kehidupan sehari-hari dan dapat meningkatkan pendapatan keluarga. Saran yang diberikan oleh para masyarakat agar kegiatan ini terus berlangsung dengan inovasi pemanfaatan produk hasil laboratorium terutama laboratorium mikrobiologi dan fisiologi Univeristas Negeri Jakarta.

\section{UCAPAN TERIMA KASIH}

Ucapan terima kasih kepada LP2M UNJ dan FMIPA UNJ yang telah mendanai kegiatan ini melalui skema Pengabdian Masyarakat Berbasis Riset tahun 2019 dengan judul "Mycogurt Pemberdayaan Ibu Rumah Tangga Dalam Peningkatan Pendapatan Masyarakat" atas nama Dalia Sukamwati.

\section{DAFTAR PUSTAKA}

Amorim, J. C., Piccoli, R. H., \& Duarte, W. F. (2018). Probiotic potential of yeasts isolated from pineapple and their use in the elaboration of potentially functional fermented beverages. Food Research International, 107(2017), 518-527. https://doi.org/10.1016/j.foodres.2018.02.054

Collado, M., Isolauri, E., Salminen, S., \& Sanz, Y. (2009). The Impact of Probiotic on Gut Health. Current Drug Metabolism, 10(1), 68-78. https://doi.org/10.2174/138920009787048437

Czerucka, D., Piche, T., \& Rampal, P. (2007). Review article: Yeast as probiotics Saccharomyces boulardii. Alimentary Pharmacology and Therapeutics, 26(6), 767778. https://doi.org/10.1111/j.1365-2036.2007.03442.x

Damian, C. (2014). Influence of Dietary Fiber Addition on the Properties of Probiotic Yogurt. International Journal of Chemical Engineering and Applications, 5(5), 397401. https://doi.org/10.7763/ijcea.2014.v5.417

FAO/WHO. (2006). Report of joint FAO/WHO expert consultation on evalua- tion of health and nutritional properties of probiotics in food including powder milk with live lactic acid bacteria. Cordoba, Argentina, 1-4 October 2001.

Fatmawati, U., Prasetyo, F., T.A, M. S., \& Utami, A. N. (2013).Karakteristik Yogurt yang terbuat dari berbagai Jenis Susu dengan Penambahan Kultur Campuran Lactobacillus bulgaricus dan Streptococcus thermophillus. Bioedukasi UNS, 6(2), $1-9$.

Fuller, R. (1992). Probiotics. Edinburgh: Springer Science+Business Media Dordrecht.

Gilliland, S. E. (1979). Beneficial Interrelationships Between Certain Microorganisms and Humans : Candidate Microorganisms for Use as Dietary Adjuncts 1 • 2, 42(2), 164-167. 
Hanzen, W. F. E., Hastuti, U. S., \& Lukiati, B. (2016). Kualitas Yoghurt Dari Kulit Buah Naga Berdasarkan Variasi Spesies dan Macam Gula Ditinjau Dari Tekstur, Aroma , Rasa dan Kadar Asam Laktat. Proceeding Biology Educational Conference (ISSN: 2528-5742), 13(1), 849-856.

Ishmayana, S., Juanda, A., Suprijana, O., Djajasoepena, S., Idar, I., \& Rachman, S. D. (2015). Pengaruh Konsumsi Yogurt yang dibuat dengan Kultur Dua Bakteri (Sterptococcus thermophillus dan Lactobacillus bulgaricus) dan Tiga Bakteri (Sterptococcus thermophillus, Lactobacillus bulgaricus dan Lactobacillus acidophilus) Terhadap Kadar Kolesterol Serum Darah Tikus. Chimica et Natura Acta, 3(3). https://doi.org/10.24198/cna.v3.n3.9302

Jannah, A. M., Legowo, A. M., Pramono, Y. B., \& Al-baarri, A. N. (2014). Total Bakteri Asam Laktat, pH , Keasaman , Citarasa dan Kesukaan Yogurt Drink dengan Penambahan Ekstrak Buah Belimbing, 3(2).

Kõll-Klais, P., Mändar, R., Leibur, E., Marcotte, H., Hammarström, L., \& Mikelsaar, M. (2005). Oral lactobacilli in chronic periodontitis and periodontal health: Species composition and antimicrobial activity. Oral Microbiology and Immunology, 20(6), 354-361. https://doi.org/10.1111/j.1399-302X.2005.00239.x

Liong, M. T., \& Shah, N. P. (2005). Optimization of Cholesterol Removal by Probiotics in the Presence of Prebiotics by Using a Response Surface Method, 71(4), 17451753. https://doi.org/10.1128/AEM.71.4.1745

Naga, W. S., Adiguna, B., Retnoningtyas, E. S., \& Ayucitra, A. (2010). Koagulasi Protein dari Ekstrak Biji Kecipir dengan Metode Pemanasan. Jurnal Widya Teknik, 9(1), 111 .

Salminen, S., Nybom, S., Meriluoto, J., Collado, M. C., Vesterlund, S., \& El-nezami, H. (2010). Interaction of probiotics and pathogens - benefits to human health? Current Opinion in Biotechnology, 21(2), 157-167. https://doi.org/10.1016/j.copbio.2010.03.016

Shukla, G., Sharma, G., \& Goyal, N. (2010). Probiotic Characterization of Lactobacilli and Yeast Strains Isolated from Whey Beverage and Therapeutic Potential of Lactobacillus Yoghurt in Murine Giardiasis. American Journal of Biomedical Sciences, 2(3), 248-261. https://doi.org/10.5099/aj100300248

Zakaria, Y. 2008. Sifat Kimia, Mikrobiologi dan Organoleptik Yogurt yang Menggunakan Persentase Lactobacillus casei dan Kadar Gula yang Berbeda. Jurnal Agripet, 8 (1) : 21-24 